Journal of Social Sciences 3 (2): 78-87, 2007

ISSN 1549-3652

(C) 2007 Science Publications

\title{
Limits and Opportunities for Autonomous User Organisations in Denmark and Sweden
}

\author{
Jørgen Anker \\ Department of Society and Globalisation (25.3), \\ Roskilde University, Box 260, 4000 Roskilde, Denmark
}

\begin{abstract}
The Nordic welfare states generally support and facilitate the formation of civil society organisations and they provide relatively good opportunities for participation and interest mediation. The Nordic welfare states are also recognised for their efforts to limit social inequality and for seeking to provide acceptable living conditions even for the most vulnerable and excluded groups. This article focuses on the opportunities for the participation for drug users, which is one of the most marginalised groups in society. Taking the cases of Denmark and Sweden, it explores the extent to which it has been possible for people who currently use drugs to organise and gain recognition as legitimate spokesmen for drug users - even when they favour strategies that are not part of the official welfare state policy. The article shows that opportunities for the autonomous organisation of drug users have been better in Denmark than in Sweden. It argues that this can be explained by different approaches to addiction and state intervention. The article thus highlights some ideological differences between the two Nordic welfare states. The article also argues that drug policies in the Nordic countries appear to be converging.
\end{abstract}

Keywords: Nordic welfare state, drug policy, social movements, drug users

\section{INTRODUCTION}

A number of different groups of social welfare users have emerged and organised themselves during the last decades. Elderly, people with physical or psychological disabilities, patient groups, homeless people and unemployed people have organised in minor self-help and interest organisations to struggle for rights and improvements in their situation in society. This development has been seen in all the Nordic welfare states and many of the organisations have, when recognised by the state, also been supported financially by the authorities.

This article explores and explains the different histories of drug users' interest organisations in Sweden and Denmark. The article argues that an analysis of the history of two drug user organisations, those of opiate users and people in maintenance treatment with methadone, provides an improved understanding of certain cultural and ideological differences between the two Nordic welfare states. Even if the Nordic welfare states in principle seek to improve the conditions of poor and marginalized citizens, Denmark and Sweden have in the last two decades provided rather distinct opportunities and conditions for drug users who seek to develop interest organisations.
In the literature on the Nordic welfare states, the existence of a specific Nordic model of welfare tends to emphasise the vast degree of similarity between the Nordic countries. In this article, however, the history and the relative position and strength of the interest organisations of active drug users serve as paradigmatic cases to illustrate and explore some of the differences between two of the countries that belong to the Nordic model ${ }^{[1]}$. One of the ideals of the Nordic welfare state is to provide welfare for all citizens, i.e. good living conditions with social and economic security ${ }^{[2]}$. The Nordic countries have been characterised by a long tradition of political democracy and a high degree of popular participation, mostly dominated by a political culture that has sought peaceful solutions to political and social conflicts. Social movements and civil society organisations have generally played a significant role in the development of the welfare state and the rather vibrant civil society in fact seems to go well together with the relatively strong welfare states ${ }^{[3,4]}$. Moreover, seen in an international comparative perspective, the Nordic countries have been characterised by a relatively high standard of living and social equality ${ }^{[5]}$.

However, even if the countries that belong to the Nordic model share an ideal of welfare for all citizens, the more specific strategies adopted to reach this aim

Corresponding Author: Jørgen Anker, Assis. Prof., Ph.D., Department of Society and Globalisation (25.3), Roskilde University, Box 260, 4000 Roskilde, Denmark, Tel: +454674 2176, Fax: +454674 3080 
diverge. One of the fields where the differences are most visible is the national approaches to alcohol and drug use ${ }^{[6]}$. The focus on drug policies in this article therefore, not only explains the different opportunities available to organised initiatives of drug users in Sweden and Denmark, it also highlights how the states emphasise different approaches and strategies to ensure welfare for all in the two countries. Sweden being more paternalistic and dogmatic and Denmark more liberal and pragmatic ${ }^{[7]}$.

\section{MATERIALS AND METHODS}

The analytical background for the arguments in this article is based on social movement theory and the assumption that resources and opportunities are needed to form social movements. More specifically, the analysis relies on the thesis that elements in the political and social environment impose constraints or open possibilities for political activity, as is in the case discussed here, the formation of interest organisations by drug users. Social movement theory often looks at the specific dimensions of the political environment which either encourage or discourage people from organising ${ }^{[8]}$. Yet in this case rather than looking at the political environment as such, the analysis departs from the assumption that drug users' opportunities to form autonomous organisations are conditioned by the national drug policies in the two countries.

The article relies on available data from Sweden and Denmark concerning the drug situation, the number of people in treatment etc. These data are used as a background for comparing and discussing differences between drug policies in the two countries. It should be noted that the methods of data collection, sampling sizes, policy frames and definitions vary according to national standards and may thus accordingly influence the precision and validity of the estimates ${ }^{[9]}$. This is not considered to be a major problem here, however, as the figures are mostly provided to give background information on the drug situation in the two countries.

The article is also based on observations from a qualitative study of user organisations among homeless people and drug users in Denmark and the author's involvement in a comparative project which aimed to map and understand the emergence of drug user organisations and user participation in the Nordic countries and the Netherlands ${ }^{[10]}$. For more than a year, the author visited the Danish drug user union and took part in informal conversations with activists. Seven formal tape-recorded qualitative interviews were done with activists in the organisation and two tape-recorded interviews with the Parent Organisation that is located in the offices of the DDUU were made. Documents from the organisation (the president's annual reports, internal minutes (so called duty reports) of daily activities etc.) have also been analysed. The analysis of the Swedish drug user organisation is primarily based on secondary data from other researchers and on analysis of documents that are available on the homepage of the organisation. Moreover, the analysis relies on informal conversations and one tape-recorded telephone interview with the chairman of the Swedish drug user organisation.

\section{RESULTS}

Drug users' interest organisations in Denmark and Sweden: Drug users' interest organisations are formed and run by drug users and they act to promote the rights and interests of drug users in society ${ }^{[1]}$. Drug users' interest organisations basically face many of the same dilemmas as any other organisation that seeks to represent a group of citizens in the public. They have to decide on strategies, aims, how to obtain resources, who to co-operate with and so on. What makes interest organisations of drug users special, however, is that their constituency and activists belong to one of the most marginalised groups in society. When the members are troubled by many other problems, it may be difficult to ensure stability and continuity in an organisation. Moreover, drug user organisations face another challenge because they often are considered with scepticism or even suspicion by the surroundings. The illegal character of production, trade, possession and - to some extent - use of drugs place drug users' organisations in a difficult position, as they may easily be taken as criminal and therefore illegitimate organisations. To avoid this, an organisation which seeks to represent drug users must frame their raison d'être from a human rights perspective, from a social political or a public-health perspective, promoting a concern and respect for the living conditions of drug users.

In spite of the problems with stigmatisation, lack of stability and scepticism towards drug users' abilities to run an organisation, an interest organisation of drug users - the Danish Drug Users Union (DDUU) was formed in Denmark in 1993. It was supported by a group of relatives and by some professionals in the field (health personal etc.). For some years, the organisation remained rather weak and vulnerable but since 1996 it gradually strengthened its position as a legitimate interest organisation. The organisation gained access to policy-making networks and the president had a seat in the National drug council from 1999 to 2002, when the 
council was closed down. Moreover, the organisation receives approximately 138,500 US\$ annually from central and local authorities for running costs. The DDUU has 160 paying members and 387 passive members ${ }^{[12]}$.

The overall aim of the Danish Drug User Union is to represent and further the interests of drug and methadone users. Moreover, the organisation opposes discrimination and it seeks to remedy powerlessness. The DDUU tries to detach itself from the denomination of drug abusers or drug addicts. It refers to its members as active users, meaning that they are not just helpless victims but citizens with rights and resources. The organisation runs a drop in centre for drug users and it has support, information and advice activities. It works to expose the social, political and economic conditions in the drugs field and to uncover how these conditions affect the individual drug user. The organisation emphasises working both politically and as a self help organisation ${ }^{[13]}$. Much of the work of the organisation aims at criticising practices in the treatment system or the social welfare system which tends to discriminate drug users. Moreover, the organisation advocates and campaigns for further harm reduction measures in drug policy, for example injection sites or heroine trials.

In Sweden, drug users have had more difficulties establishing an interest organisation. Even though the Swedish welfare state also supports voluntary and client organisations, an organisation run by drug users was formed ten years later than in Denmark. Different client organisations have spoken on behalf of drug users in Sweden for many years, but they have not been organised by people who were currently using drugs. Yet, in 2002, the first organisation of opiate users and people in maintenance treatment was organised. The organisation (Brukarforeningen) was supported by the NGO, RFHL (National Association for Aid to People Addictive to Drugs and Pharmaceuticals) and in the beginning it was hosted by the RFHL. After a year, in 2003, the user organisation sought to become more independent to avoid unwanted control by non-users, in particular, its constituency - drug users - were not allowed into the premises if they were visibly influenced by drugs, so the organisation moved to another place.

The Swedish Users Union represents opiate users and people who need or are in maintenance treatment. The motivation to form the organisation emerged because many drug users experienced that they could not get maintenance treatment with methadone because of an abstinence oriented drug policy. The organisation has approximately 1,000 user members ${ }^{[14]}$. Many of the aims of the Swedish organisation are similar to the
Danish organisation and the two organisations cooperate, yet working in the Swedish context means that different strategies are applied. Slowly, the Swedish drug user organisation has also gained support from both central and local authorities. This is reflected in state support for the organisation and in 2007, it is expected that it will receive approximately 92,000 US\$ to support its work nationally and at the local level, in Stockholm.

The Swedish interest organisation seeks to balance its claims carefully to be able to continue gaining recognition and support from the authorities. The main difference between the Danish and Swedish organisations, the chairman argues, is that in Denmark everything can be said, while in Sweden it is impossible to talk about issues that are not accepted within the dominant drug policy ideology. Whereas the Danish drug user union thus speaks openly in favour of injection rooms or heroine trials, the Swedish user organisation remains silent on these issues.

To sum up, both the Danish and the Swedish drug user organisations emerged in relation to treatment systems and they argued for respect and decent treatment. They seek to improve the conditions for people using heroine and for drug users in maintenance treatment with methadone. Moreover, both organisations are today recognised and supported by their respective national authorities. In Denmark, the user organisation seeks to call attention to more liberal practices such as heroine trials and injection rooms, but in Sweden the user organisation calls for improved access to maintenance treatment with methadone and for further syringe exchange programmes.

The question is why it took ten more years - after the DDUU was formed - before a drug user interest organisation could be formed in Sweden and why the two organisations have rather different, specific, policy aims in these two neighbouring countries? The explanation, this article argues, is to be found in the drug policy of the two countries.

Sweden - a restrictive policy: In Sweden, it is estimated that there are approximately $26,000-28,000$ so-called problematic drug users ${ }^{[15,16]}$. Traditionally, drug use in Sweden was dominated by intravenous amphetamine use, yet heroine use has increased steadily since the late $1970 \mathrm{~s}^{[16]}$. In 2003, 3,376 injecting drug users were in different kinds of treatment in Sweden ${ }^{[15]}$. Maintenance treatment has not been applied on a large scale and has always been surrounded by strict regulations with a centrally determined fixed roof of the number of people that are allowed into methadone maintenance treatment. A few years ago, this roof was 
raised from 800 to 1200 patients $^{[15]}$. In 2003, the number of drug related deaths in Sweden is - according to the last official statistics $152^{[16]}$. Goldberg ${ }^{[17]}$ however questions the official numbers and based on alternative data from the medico-legal institute he argues that Sweden had 425 drug related deaths in 2002.

Sweden has been dominated by a restrictive drug policy since the 1970s with the guiding principle of seeking to achieve a "drug free society." In the late 1960 s, the Swedish drug policy was defined as an interaction between prevention, penal control and the treatment of drug users. This policy has been followed since then, but in the late 1970s Swedish drug policy gained a more restrictive character. In 1977 the Swedish parliament (Riksdagen) decided that the aim of Swedish drug policy would be a drug-free society ${ }^{[18]}$. Consequently, control measures were given a higher priority. Until the late 1970 s, penal control had concentrated primarily upon producers, importers and big dealers. But the shift implied that not only dealers, importers and producers but also drug users - the marginalised groups on the street - were met with coercive strategies $^{[19]}$. Firstly there was the new controldominated strategy aimed at clearing the streets of drug pushers, who were to be placed in compulsory treatment. Secondly, all forms of possession of drugs were to be prosecuted ${ }^{[8]}$. The argument was that the drug user was the indispensable link in the drug chain and therefore every effort should be taken to prevent the drug abuser from using drugs through penal control and coercive treatment ${ }^{[19]}$. A police representative in a government report from 1991 explicitly wrote, that it should "be difficult to be a drug user",[20].

The importance of sending a univocal message to drug users, demonstrating that society strongly repudiates any use of drugs additionally implied that the coercive model was marked by resistance to syringe exchanges and by opposition to the expansion of methadone programmes ${ }^{[19]}$. One of the best examples of how this orientation was implemented in practice is the Swedish reaction when HIV and AIDS opened the way for harm reduction practices in the form of syringe exchange programmes in many other countries ${ }^{[18]}$. In Sweden, syringe exchange was rejected, because such measures conflicted with the overall aim of the drug free society. Instead the Swedish government held that the way to deal with the menace of HIV and AIDS was to reach all intravenous drug users with detoxification, sampling and treatment ${ }^{[18]}$. Locally, syringe exchange programmes were later opened in the South of Sweden, but these initiatives sparked a lot of debate and attempts by central authorities to close down the programmes.
Finally, it should be mentioned that in Sweden compulsory treatment is used although on a very limited scale and basically as a means to motivate the individual to enter into a voluntary treatment measure. In 2000, over 1,100 people were in compulsory treatment (most of these for alcohol addiction, however ${ }^{[21]}$. In 2005 , the authorities took the decision to provide compulsory care for 870 persons ${ }^{[22]}$.

The rationality behind the restrictive and coercive elements of the drug policy lies in an ideological commitment to take care of those who cannot take care of themselves - even if it is against the will of the potential recipient of assistance ${ }^{[19]}$.

Denmark - a combination of control and harm reduction measures: The number of drug users in Denmark is almost the same as in Sweden. It is estimated that approximately 27,000 drug users have an ongoing use of drugs which causes social, physical, or psychical harm ${ }^{[23]}$. In 2005, approximately 13,300 persons took part in some kind of treatment programme during the year ${ }^{[23]} .56 \%$ of these were injecting heroine users equivalent to approximately 7,450 people. In 2004, 5,700 persons received substitution treatment with methadone and to this could be added 600 persons in substitution treatment with buprenorphine. In Denmark, there were 275 drug related deaths in 2005, of which $75 \%$ (206) were caused directly by the consumption of one or more drugs ${ }^{[23]}$.

Compared to Sweden, Denmark has been one of the more liberal countries in Europe, concerning drug policies. Denmark also has an ultimate aim of creating a society without drugs, but at the same time, harm reduction initiatives are an integrated and accepted part of drug policy. Policies and discourses on drugs are, however, multifaceted and not characterised by clarity of principles or strategies. In practice this means that drug policies in Denmark are often based on rather pragmatic considerations. They may thus be defined as containing a little of everything because they combine prevention, control and different forms of treatment strategies $^{[24,25]}$.

Many policy papers, including the Danish Government's latest white paper on drug strategies, refer to an ideal of creating a society without drugg ${ }^{[26]}$. Yet at the same time it is also stated that this in reality is impossible and that to some of the most affected groups of drug users, harm reduction measures are very important because abstinence in practice remains unrealistic $^{[26,27]}$. Harm reduction initiatives are thus an integrated and accepted part of the official Danish policy as long as they are not considered to contradict an overall aim of bringing the use of illicit drugs to an 
end. In recent years, a more restrictive line of the drug policy has been seen ${ }^{[24]}$, but still, the drug policy of the late 1980s and the 1990s provided the necessary opportunities for a drug user organisation to emerge and consolidate.

The harm reduction strategies are defined as integrated, pragmatic and reasonable approaches to reduce the socially and health-related harm that is related to drug use ${ }^{[26]}$. This means that syringes are handed out for free at institutions, shelters etc. for homeless people and drug users. Further, maintenance treatment with methadone is broadly accepted in Denmark together with low-threshold services for drug users. The acceptance of harm reduction measures have some limits, however. Attempts to introduce more liberal measures such as experiments with heroine, the establishment of safe injection rooms, or liberalisation of the cannabis regulation are examples of initiatives that have not been allowed by the central authorities. There have been a number of attempts to pressurise for more liberal measures, but most of these have failed, though seldom because of outright decisions based on principles $^{[11]}$. The free "city" of Christiania has thus been allowed to exist with its open cannabis market for many years, as an outcome of an uneasy balance between repressive drug policies and more liberal and pragmatic welfare philosophies. As Laursen and Jepsen $^{[11]}$ note in the implementation of Danish drug policies, different considerations often exist side by side and when new proposals are turned down it is often for fairly unclear reasons.

One recent example of local struggles for harm reduction initiatives can be found in Copenhagen. Neighbours to the open drug scene at Vesterbro have been mobilising arguing that a safe injection room should be opened to limit public nuisance related to open drug consumption in the streets. The Municipality of Copenhagen has also supported the establishment of an injection room and in 2003 and 2005 the political opposition parties proposed to allow the establishment of an injection room. The proposals were turned down by the Government however, claiming that injection rooms would contradict the attempt to counter any nonmedical use of drugs ${ }^{[26]}$. While not approved in practice, the debate on injection rooms has been going on for many years in Denmark. In Sweden a similar debate or proposal appears un-imaginable and almost absurd $^{[28]}$.

Summing up, in Denmark the aim of drug policies is also to gain a society without drugs, but in practice approaches and policies combine this idealistic principle with more pragmatic concerns related to reducing the harms that drug users face.
Maintenance treatment - improved conditions for concerted action: The different policy-lines in the two countries provided different spaces from where drug users could unite, develop shared interests and organise. One such possible space is the sphere of maintenance treatment which was developed rather differently in Denmark and Sweden.

The social situation of drug users is of vital importance to the formation of interest organisations of drug users. The chaotic living conditions of drug users who have to spend all their energy on gathering money to buy drugs obviously limits the energy available for becoming involved in collective action. If drug users do not have the possibility for living a relatively stable life, it will be difficult to invest resources into working in an interest organisation. In this respect, methadone maintenance treatment may provide an important (though not the only) facilitating dimension in the process of forming drug users' organisations.

Methadone maintenance treatment may provide more stable living conditions for drug users and thus increase the number of activists who can effectively participate in the work of an interest organisation. Moreover, the extension of methadone treatment means that groups of drug users begin to meet each other in an environment which treats people with some kind of standardised measures. In this space, the development of a collective identity and a shared concern for changing specific dimensions of drug users' lives can more easily be developed than in an individual and desperate struggle for drugs that takes place in the street.

In other words, methadone maintenance treatment allows drug users to organise as drug users. It provides an institutional opening for drug users to create and maintain a public identity as users of public welfare services: Users with rights and voices.

In Denmark, the extension of maintenance treatment programmes using methadone enabled certain groups of drug users to create sufficiently stable living conditions to engage actively in the formation of interest organisations. But Sweden maintained a restrictive stance to methadone treatment.

Sweden actually introduced maintenance treatment with methadone as one of the first countries in the world ${ }^{[20]}$. Later maintenance treatment programmes using methadone became very limited, partly because of pressure from some of the client organisations in the field. For many years, there was persistent opposition and criticism against methadone treatment in Sweden as it was considered a form of legal abuse. Much of that attitude changed with the HIV epidemic, however, albeit not immediately ${ }^{[29]}$. The methadone programmes 
in Sweden are officially oriented towards total abstinence ${ }^{[18]}$. This more idealistic aim of maintenance treatment is combined with more control with patients in methadone programmes. Doses are gradually lowered and the patients are not informed about the quantity of methadone they receive. Urine screenings are carried out to ensure that there is no leakage from the programme and to ascertain that patients do not use illegal drugs ${ }^{[29]}$. If traces of heroine are found, the patient is expelled from the methadone programme and excluded for two years.

The approach to methadone maintenance treatment in Denmark is less idealistic and does not carry within it an ambition of 'saving' the drug user from using drugs. Moreover, urine screenings have been limited and stopped in most methadone treatment during the last few years partly because of pressure from the Danish Drug User Union, which has criticised control-oriented practices and philosophies in maintenance treatment with methadone for many years.

In Denmark there is a general acceptance that a variety of different treatment methods is necessary to cover the different individual needs of drug users. For some drug users, drug free treatment is the solution and for others, maintenance treatment with methadone is an alternative. In Sweden however, treatment is first and foremost understood from the perspective of gaining a society free of drugs $^{[30]}$ and in this perspective maintenance treatment with methadone is only the last and final solution. If a drug user, however, is unable or unwilling to fulfil the requirements of living a life without using drugs, it may lead to exclusion of the drug user from the treatment programmes and from certain social welfare offers.

\section{DISCUSSION}

Gaining a space for action in Sweden and Denmark: The Scandinavian welfare states have generally facilitated the emergence of a number of voluntary organisations and there has been a long tradition of including organisations in the political-administrative process $^{[31]}$. However, when it comes to organisations organised by drug users themselves, distinctive traits and different ideological and moral climates have provided varied opportunities and spaces for manoeuvre.

To gain legitimacy, a new interest organisation must be able to carve out a space within the established system, from where it may gradually extend its activities. It has to depart from and refer to a standpoint which is already accepted and which can be used to expand its space of legitimacy. In a country where drug users' lifestyles are neglected and perceived as unwanted, destructive and harmful to society, the threat of being met with repressive measures may lead drug users to prefer isolation rather than collective organisation. The personal calculation of costs in relation to possible gains of collective action may simply mean that drug users refrain from activities which will call further attention to themselves and their life as drug users. In this light, it appears that the Swedish drug policy in the 1990s thus tended to drive drug users into isolation ${ }^{[9]}$, whereas the Danish drug policy with its more ambivalent dimensions of control and harm reduction measures, provided an opportunity for drug users to speak up and make claims.

The Swedish discourse on drugs has been moved by much more uniform moral and ideological arguments, which has their legitimacy in a restrictive approach to alcohol policy. The restrictive approach to alcohol sought through external - state driven - control to limit the consumption of alcohol. This ideology and practice was rooted in the traditional strength and success of the temperance movement which emerged in the nineteenth century in relation to the problems that accompanied high alcohol consumption ${ }^{[18]}$. The same logics of restriction and control were later obvious solutions to deal with the drug problem.

The strength of the temperance movement ensured a broad popular support for restrictive policies on drugs and alcohol ${ }^{[18]}$. This has also meant that the drugs field (with the exception of the more ambivalent position of RFHL) has been dominated almost entirely by controloriented organisations which have been able to gain significant political power and silence alternative voices. Three organisations, 'Parents against drugs' $(F M N)$, the Hassela Solidarity Organisation and the National Association for a Drug Free Society have been the most important players. The control-oriented NGOs have been keen to and successful in rejecting the legitimacy of any argument that favoured harm reduction strategies ${ }^{[20]}$. Abstinence-related arguments have thus remained familiar to and part of the national framework for drugs and treatment. The introduction of compulsory treatment and the criminalisation of drug use was in fact a demand which emerged from the NGOs $^{[18]}$.

Moreover, the character of the welfare state and the institutional structures which regulate the relationship between civil society and the state is rather centralised and hegemonic in Sweden. The active policy of state intervention is based on a centralised and hierarchical institutional system, with close corporatist links between interest organisations (e.g. the workers' movement or the temperance movement) and the 
state $^{[32]}$. Alternative forces and movements (e.g. the environmental movements) are quickly sought integrated and absorbed by the parliamentary system and the institutional structure of the state ${ }^{[33]}$.

All this indicates that in Sweden, the space for alternative and more liberal arguments has been restricted. Actors favouring harm reduction measures and challenging the consensus in the system - have been portrayed as constituting a significant threat to ideals and struggle for a drug-free Sweden ${ }^{[34]}$. There has been almost no credibility for a position equated with a drug-liberal stance ${ }^{[18]}$. In this climate, to acknowledge opiate or methadone users' rights to organise as drug users would be almost the same as giving up to the enemy.

The Danish discourse, on the other hand, has been much more pluralistic, politically pragmatic and marked by more practical considerations of feasibility and consequences ${ }^{[35]}$. This has opened more opportunities for alternative voices to gain access and legitimacy in Denmark. The mix of a soft rhetoric at the political level combined with both control and harm reducing initiatives in practice ${ }^{[36]}$, simply provided a more fertile ground for an interest organisation of drug users.

Whereas the dominating organisations in the drug field in Sweden all supported a restrictive and control oriented policy, the drug field in Denmark was characterised by a more pluralistic spectrum of organisations, treatment communities and parents' organisations with different aims and ideologies. In short, a more pluralistic and potentially favourable environment, with the presence of potential allied actors may help explain the earlier emergence of drug user organisations in Denmark ${ }^{[10]}$. Of particular importance to the Danish Drug User Union was the presence of an organisation of relatives to drug users ("Parents Association to drugs-influenced children; Forceldreforeningen til Narkoramte børn). This organisation was formed in 1974 and it explicitly aimed at seeking to obtain a general acceptance of methadone maintenance treatment in Denmark. The organisation became a central support in the process of forming the drug users' union and it has remained a close ally to the organisation ever since.

It is also of importance that the political legitimacy of the Danish Drug User Union was facilitated by the formation of close links to the Ministry of Social Affairs and other key actors in the field. The Ministry of Social Affairs has always supported more pragmatic harm reduction strategies and the concern for drug users' living conditions played well together with the ambitions of the Ministry of Social Affairs to enable and support user organisations by marginalised groups.

As Eyerman and Jamison argue, with reference to the environmental movement, in Denmark there is also a much stronger tradition of extra-parliamentary movements ${ }^{[33]}$. This stronger tradition of alternative forms of politics and a more multifaceted underground culture $^{[37]}$ has provided a wider range of options for those who challenge the system. Grass-root initiatives (or open contradictions to drug policies such as the free city Christiania) are to a wider extent allowed to exist, next to the sphere of institutional politics. Such experiments with alternative lifestyles, community forms, youth culture, etc. have provided a more liberal approach to and a more open space and acceptance of groups that seek to represent alternative normative standpoints - even if they basically contradict the official policy of the welfare state.

Different beliefs in the state: However, the different opportunities of drug users' interest organisations are also rooted in divergent commitments to the ideal and role of the welfare state. The acceptance and degree of state intervention in a deviant citizen's life is different in the two countries. In both countries the welfare state is expected to provide welfare for all, but the state's right to limit what individuals can say and do to achieve this aim is different.

In Sweden, where liberal ideas, according to Tham ${ }^{[19]}$ had minor influence in the nineteenth century, it is more difficult to argue in terms of civil liberties, e.g. of the limits of state power in relation to its citizens. The goal of the drug free society therefore tended to downplay public debate and discussion on the costs of such a policy, for example high penalty levels and encroachments on civil liberties ${ }^{[19]}$. The model and the slogan of 'a drug-free Sweden', tended to put society before the individual ${ }^{[34]}$ and it goes well together with a strong dedication to maintaining a strong and active welfare state.

Tham $^{[34]}$ thus argues that the acceptance of harm reduction programmes would be seen as a failure for social policy in Sweden. The life of the drug user is seen as the antithesis to the life of the good citizen in Sweden ${ }^{[9]}$. Alleviating the suffering of individual drug users would undermine the motivation for living a life without drugs. On the other hand, to put pressure on individual drug users is not questioned, because it serves a higher and more important aim in the end.

Yet, the rejection of adopting more pragmatic and harm reducing measures to alleviate the situation for the individual drug user, also signals a more idealistic 
concern for citizenship in Sweden than in Denmark. Drug use is also condemned and rejected in Denmark but it is - as other forms of social deviance - approached by more pluralistic, liberal and pragmatic strategies. Even if many social welfare strategies in Denmark share the ambitions that are expressed by a technocratic social engineering tradition in Sweden, the implementation of these policies in practice remains more pragmatic and pluralist ${ }^{[35]}$. A stronger belief in the capacity of the state to change society ${ }^{[18]}$ kept strategies more uniform and in line with the overall principle in Sweden.

Shared conditions: The increasing organisation of users of social services must be seen in relation to new strategies of empowerment, liberalisation and an increased emphasis on service users' rights to make free choices in the welfare state. In Denmark this development has been combined with an effort to ensure welfare users' rights to organise. These rights to form user councils were inscribed in the social legislation in the $1990 \mathrm{~s}^{[38]}$. The same development is now also seen in Sweden and it opens up new opportunities for the formation of interest organisations of drug users and other groups of marginalised people, who are able to define shared interests and strategies.

It is important to emphasise that even if the drug user organisations have faced different opportunities for participation and interest mediation in the two countries, they by and large confront the same kind of problems. Drugs are related to an understanding of dependency and irresponsible search for pleasure. In many ways, drugs and drug users thus represent an antithesis to the ascetic work moral that is deeply rooted in the Calvinist Nordic culture ${ }^{[17]}$. The formation of organisations of drug users in other words challenges some of the core ideals of a society and a welfare state which has been strongly influenced by the workers' movements and its work-ethic ideals. Drug users' interest organisations exist and act in a universe that, to a certain extent, questions their very right to exist. Both in Denmark and Sweden, populist-inspired politicians have occasionally questioned the state's support for drug users' organisations. Both the Danish and the Swedish drug user organisation therefore have to balance their claims and strategies very carefully, without provoking feelings and reactions which could question their legitimacy.

The philosophy of user involvement, however, may indeed also turn out as a good investment for the authorities if they recognise and co-operate with drug user organisations. Recent studies on the importance of drug user organisations suggest that drug user organisations may perform a critical public health function by providing care and support programmes that are responsive to immediate needs of their peers ${ }^{[39]}$. Drug user organisations may thus serve as important intermediate actors - a tool for the welfare state - to reach some of the most marginalised injecting drug users.

Recent developments: Finally, it should be noted that since the early 1970's Denmark has been pressurised by its Swedish neighbours to take a more restrictive position on drug policies ${ }^{[35]}$. Moreover, Danish penal and drug policies have been tightened up during the last $5-10$ years leading to stricter penalties, allocation of more resources to the police, the construction of new prisons, prison departments for special groups etc. A more restrictive policy on cannabis has also been introduced. Traditionally, possession of cannabis for one's own use has not been fined, but only released a warning from the police. According to bill no. 175, however, the first time reaction is now a fine and repeated offences will give harder penalties (higher fines or prison) ${ }^{[40]}$. Additionally, the police have made a lot of efforts to close down the open cannabis market in Christiania.

On the other hand, it appears that the hegemonic position of a very restrictive drug policy as the only imaginable possibility is being challenged in Sweden, invariably opening a new space and new opportunities for drug users' collective organisation ${ }^{[14]}$. Some of the indications are reflected in the fact that an increased number of drug users have been allowed into the maintenance treatment programmes with methadone in Sweden. The parliament also approved syringe exchange programmes in 2006, but administrative procedures and local authorities may still limit the implementation in practice. It seems, in other words, that harm reduction measures are increasingly gaining acceptance in Sweden as part of a public health concern, even if it is not linked to a human rights perspective ${ }^{[14]}$. The appearance of a user organisation organised by drug users themselves in fact also appears to incite this development.

While the Danish drug policies seem to move towards more restrictive practices, Sweden appears to be opening up for slightly more pragmatic stances towards drug policies and treatment. In this sense, the developments in the two welfare states seem to move in the direction of convergence - at least when it comes to drug policies. 


\section{REFERENCES}

1. Esping-Andersen, G., 1990. The three worlds of welfare capitalism. Cambridge: Polity.

2. Kildal, N. and S. Kuhnle (Eds.), 2005. Normative foundations of the welfare state: the Nordic experience. London: Routledge.

3. Svedberg, L. and E.J. Grassman, 2001. Frivilliga insatser i svensk välfärd - med utblickar mot de nordiska gannländerne. In: Frivillighedens udfordringer. Nordisk forskning om frivilligt arbejde og frivillige organisationer, (eds L.S. Henriksen and B. Ibsen) pp. 67-85. Gylling: Odense Universitetsforlag.

4. Henriksen, L.S. and B. Ibsen, 2001. Indledning: Udfordringer for frivilligheden. In: Frivillighedens udfordringer - nordisk forskning om frivilligt arbejde og frivillige organisationer (eds L.S. Henriksen and B. Ibsen) pp. 9-20 Gylling: Odense Universitetsforlag.

5. Christiansen, N.F., K. Petersen, N. Edling and P. Haave, 2006. The nordic model of welfare. København: Museum Tusculanum Press.

6. Christie, N. and K. Bruun, 1985. Den gode fiende : narkotikapolitikk i Norden., Oslo: Universitetsforlaget.

7. Tammi, T. and T. Hurme, In Press. How the harm reduction movement contrasts itself against punitive prohibition. International Journal of Drug Policy.

8. Tarrow, S., 1994. Power in movement: social movements, collective action and politics. Cambridge: Cambridge University Press.

9. Chatwin, C., 2003. Drug policy developments within the european union. the destabilizing effects of Dutch and swedish drug policies. Br. J. Criminol., 43: 567-582.

10. Anker, J., V. Asmussen, P. Kouvonen and D. Tops, 2006. Drug users and spaces for legitimate action. Helsinki: NAD.

11. Jepsen, J., 2004. BrugerforeningerSelvorganisering, interessevaretagelse og gensidig støtte. In Brugerperspektiver. Fra stofmisbrug til socialpolitik? (Eds. V. Asmussen and S. Jöhncke) pp: 169-191. Aarhus Universitetsforlag: Gylling.

12. Hansen, F.K., M. Malmgren and L.K. Minke, 2005. Brugerforeningen for aktive stofbrugere - en evaluering. København: CASA.

13. Anker, J., 2006. Active drug users-struggling for rights and recognition. In: Drug users and spaces for legitimate action. (eds J. Anker, V. Asmussen, P. Kouvonen and D. Tops) pp: 37-60 Helsinki: Nordic Council for Alcohol and Drug Research.
14. Palm, J., 2006. The consumer, the weak, the sick and the innocent. In: Drug users and spaces for legitimate action. (Eds. J. Anker, V. Asmussen, P. Kouvonen and D. Tops) pp: 159-182 Helsinki: Nordic Council for Alcohol and Drug Research.

15. Reitox, National Focal Point, 2005. Sweden New Development, Trends and in-depth information on selected issues. 2005 national report (2004 data) to the EMCDDA. Statens folkohälsainstitut and EMCCDA.

16. Centralförbundet för alkohol- och narkotikaupplusning., 2006. Drogutvecklingen i Sverige 2006. Stockholm: CAN.

17. Goldberg, T., 2005. Samhället i narkotikan. Borgå: Academic Publishing of Sweden.

18. Solinge, T.B.V., 1997. The swedish drug control system. Amsterdam: Uitgeverij Jan Mets; CEDRO.

19. Tham, H., 1998. Swedish drug policy: A successful model? Eur. J. Criminal Policy and Res., 6: 395414.

20. Lenke, L. and B. Olsson, 2002. Swedish drug policy in the first twenty-first century: A policy model going astray. The Annals, AAPSS, 582: 64-79.

21. Johnson, B., 2006. The development of user influence on Swedish drug policy 1965-2004. In Drug users and spaces for legitimate action. (Eds. J. Anker, V. Asmussen, P. Kouvonen and D. Tops) pp: 131-157. Helsinki: Nordic Council for Alcohol and Drug Research.

22. Socialstyrelsen, 2006. Vuxna personer med missbruksproblem och övriga vuxna - insatser år 2005. Statistik. Stockholm: Socialtjänst.

23. Sundhedsstyrelsen, 2006. Narkotikasituationen i Danmark 2006. København: Sundhedsstyrelsen.

24. Laursen, L. and J. Jepsen, 2002. Danish Drug Policy - An ambivalent balance between repression and welfare. The Annals, AAPSS, 582: 20-36.

25. Ege, P., 2004. Stofmisbrug + afhængighed hos unge og voksne. København: Hans Reitzels Forlag.

26. Regeringen, 2003. Kampen mod narko handlingsplan mod narkotikamisbrug. København: Indenrigs- og Sundhedsministeriet.

27. Sundhedsstyrelsen, 2004. Narkotikasituationen i Danmark 2004. København Sundhedsstyrelsen: København.

28. Svensson, B., 2005. Sprutrum från svensk horisont. Nordisk Alkohol- \& Narkotikatidskrift, 22: 62-65.

29. Skretting, A., 2006. Treatment and harm reduction measures. In: Drugs in the Nordic and Baltic countries. Common concerns, different realities (Eds. P. Kouvonen, A. Skretting and P. Rosenquist) pp: 73-104. Helsinki: Nordic Council for Alcohol and Drug Research. 
30. Ólafsdóttir, H.e., 2001. Introduksjon. In Skyldig eller sjuk? Om valet av påföljd för narkotikabruk. (Ed. Ólafsdóttir, H.e) pp: 5-12. Helsinki: Nordic Council for Alcohol and Drug Research.

31. Torpe, L., 2003. Social Capital in Denmark: A deviant case? Scandinavian Political Studies, 26: 27-48.

32. Laanemets, L., 2006. Organisation among drug users in Sweden. In Drug users and spaces for legitimate action. (Eds J. Anker, V. Asmussen, P. Kouvonen and D. Tops) pp: 105-129. Helsinki: Nordic Council for Alcohol and Drug Research.

33. Eyerman, R. and A. Jamison, 1991. Social movements: A cognitive approach. Cambridge: Polity Press in association with Basil Blackwell.

34. Tham, H., 2005. Swedish drug policy and the vision of the good society. J. Scandinavian Studies in Criminology and Crime Prevention, 6: 57-73.

35. Laursen, L., 1996. Scandinavia's tug of war on drugs. In Discussing drugs and control policy. Comparative studies on four Nordic countries. (Eds P. Hakkarainen, L. Laursen and C. Tigerstedt) pp: 33-81. Helsinki: NAD.
36. MacCoun, R. and P. Reuter, 2002. Preface: The varieties of drug control at the dawn of the twentyfirst century. The Annals, AAPSS, 582: 7-19.

37. Jamison, A., R. Eyerman and J. Læssø, 1990. The making of the new environmental consciousness: A comparative study of the environmental movements in Sweden, Denmark and the Netherlands. Edinburgh: Edinburgh Univ. Press.

38. Asmussen, V., User Participation: possibilities and limitations in Danish social services directed towards drug users. In: Regulating drugs - between users, the police and social workers. (Eds. E.H. Pedersen and C. Tigerstedt) pp: 11-32. Helsinki: Nordic Council for Alcohol and Drug Research.

39. Kerr, T., W Small, W. Peeace, D. Douglas, A. Pierre and E. Wood, 2006. Harm reduction by a 'user-run' organization: A case study of the Vancouver area network of drug users (VANDU). The Intl. J. Drug Policy, 17: 61-69.

40. Jepsen, J. 2004. What is an effective drug policy? Denmark. In: Berlin Conference: Trends in European Drug Policies. Berlin. 